\title{
THE ROLE OF EMOTIONAL QUOTIENT TO MODERATE EFFECT OF ROLE STRESS ON EXAMINER JOB PERFORMANCE IN AUDIT BOARD OF THE REPUBLIC OF INDONESIA
}

\author{
Adhelia Syarfina*, Tjaraka Heru \\ Department of Accounting, Faculty of Economics and Business, University of Airlangga, \\ Surabaya, Indonesia \\ *E-mail: syarfinaadhelia@gmail.com
}

\begin{abstract}
Auditors are often associated with work stress. One of the stresses that are often experienced by auditors in doing work is role stress. Excessive stress faced by the auditor when working and often not immediately anticipated properly, and unfavorable working conditions can also affect auditor performance. This study uses a moderator variable, namely emotional quotient. An auditor needs to have a mechanism that is able to minimize and overcome the pressure that occurs in order to be able to maintain performance that is by the presence of emotional quotient. The self-motivation of each individual will grow if affiliated with the presence of emotional quotient. Emotional quotient is expected to be in the auditor to have high performance and get a good career in his career path. This research was conducted at the Audit Board of the Republic of Indonesia with 100 respondents, with a range of research ranges from March-April 2018. The data analysis technique used in this study is the Moderated Regression Analysis (MRA). The results of this study is emotional quotient strengthen the influence of role stress on job performance examiner.
\end{abstract}

\section{KEY WORDS}

Role stress, emotional quotient, job performance, auditor.

As an independent examiner in the field of state finances, the examiner Audit Board of the Republic of Indonesia is fitting to maintain the attitude and morale in carrying out the task in hand objectively. The main task of the Audit Board of the Republic of Indonesia in conducting an examination conducted by a comprehensive process and attitude of skepticism and professionalism basically is to provide assurance that the financial statements presented by government agencies have been accounted for.

Audit Board of the Republic of Indonesia is predicted to be the spearhead to promote clean state financial management, accountable for the attainment of the country. Performance of examiner time to resolve any duties is a measure that is usually used to assess whether an assignment has been carried out with the optimal or not (Kalbers \& Fogarty, 1995), As a result, a conducive working conditions can affect the performance and results of the work of auditors, which in turn can affect public confidence in the auditor as an independent party in the process of auditing the auditee.

Auditors often associated with job stress (Rustiarini, 2014), One of the stress that is often experienced by the auditor to do the job that is the pressure (role stress). Pressure (role stress) a condition in which a person has difficulty in understanding what was his job, a role that he played were deemed too heavy, or in other words, he plays a wide variety of roles in which he worked (Kalbers \& Fogarty, 1995). Audit Board of the Republic of Indonesia, with the checkout area spread across Indonesia, the examiners are required to give the best results in the examination process. Demands to the Audit Board of the Republic of Indonesia for carrying out checks on various national issues related to state finances leading to higher workload of the Audit Board of the Republic of Indonesia.

According to the Annual Report of the Audit Board of the Republic of Indonesia in 2016, although in these years feels short on power examiner and his supporters, the number of human resources of the Audit Board of the Republic of Indonesia would shrink over the previous year, in 2015 the amount of resources human Audit Board of the Republic of 
Indonesia there are 6,438 , while in 2016 dropped to 6,295 people with a percentage number of examiners as much as $52.19 \%$. Examiner limited resources and a desire to improve the quality of the results of the examination in order to meet the public's expectations have meant that all the checks are carried out and reported in a timely manner (Schick, Gordon, \& Haka, 1990),

In fact, it is not uncommon stress intentionally allowed to increase the challenge for someone to be able to improve its performance (Fogarty, Singh, Rhoads, \& Moore, 2000), Nevertheless, negative stress is likely to result in a person doing dysfunctional behavior and reduce the quality of their work (Le Fevre, Matheny, \& Kolt, 2003), Excessive stress faced by auditors while working and often not immediately anticipated, as well as the unfavorable working conditions can also affect the performance of the auditor (Fanani, Hanif, \& Subroto, 2008), Similarly, the pressure felt by the auditor could be the reason how one behaves. When an auditor has the physical and emotional stress are excessive and go beyond their capabilities, both in the work environment of a colleague or of his superiors, they tend to act something that can injure the integrity and professionalism (Hatfield, Jackson, \& Vandervelde, 2011; Nasution \& Östermark, 2012),

Coenen (2008), give some examples of stressful circumstances include, bad financial condition of someone with so many bills to pay; the desire for a better lifestyle; or dissatisfaction with the living paycheck to paycheck. As a result, someone who suffered stress as a result of financial problems may be more likely to act unethically (Cianci \& Bierstaker, 2009),

The pressure felt by the examiner could also be the reason how one behaves so the effect on the audit opinion, when an examiner has the pressure of the working environment is not good from colleagues and from his superiors, they tend to give their opinions or judgments which can injure the integrity and professionalism (Hatfield et al., 2011; Nasution \& Östermark, 2012), According to Hatfield et al. (2011) their perceived high pressure will cause the auditors propose auditors much less an audit adjustment than those who had low pressure. Though work stress can cause job dissatisfaction and decrease performance (Chen, Silverthorne, \& Hung, 2006; Hayes \& Weathington, 2007) up can result in aberrant behavior (Lawrence \& Robinson, 2007),

Professional conduct examiner can be realized in the form of avoid dysfunctional audit behavior, the behavior of the auditor in the audit process that does not comply with audit procedures predefined or deviated from the applicable standard, which can reducing the quality of audits. Financial audit carried out to determine whether the financial statements (information verified) declared in accordance criteria or standards applicable accounting (Arens et al., 2008).

This study uses a moderator variable that is emotional quotient. The pressure that occurs in the examiner requires a mechanism to reduce these to be able to maintain and improve the performance, one of which is the presence of emotional quotient. Behavior examiner influenced by many things. For example, in the assignment of the examiner is often faced with ethical dilemmas caused conflict audit, under such conditions of emotional quotient provides vital role how an accountant can complete the job in a work environment. Motivation will arise in a person, if it had its impetus with emotional quotient. Emotional quotient is expected to exist within the examiner in order to improve performance as well as high career. Furthermore, the necessary emotional quotient as the ability to control emotions and feelings that exist within, and how these capabilities can be used when interacting well with others.

From the results of research conducted by Cote \& Miners (2006), Employees with low IQ levels can give a good performance and often participate in Organizational Citizenship Behavior (OCB) if they have a stable emotional quotient. According to Kip Holderness \& Hunton (2010) high understanding of how to improve physical and psychological health will increase the benefits to individuals, organizations, and communities. Many researchers agree that the intellectual's contribution towards the path of success only takes $20 \%$, and the rest depends on all the things that are developed in the human brain over millions of years of human evolution (Gibbs \& Epperson, 1995), Similarly, in a study conducted byErmawati, 
Sinarwati, \& Edy Sujana (2014); Notoprasetio (2012) Emotional intelligence is proven to affect the performance of an auditor.

Good emotional quotient can make someone for not misbehaving and can achieve satisfactory performance. Emotional quotient has a function that is quite significant, to shape the behavior and habits in one individual to the level of emotional quotient are fulfilled will be easier to deal with problems that occur, so that he could avoid the stress, able to control themselves better, interact socially well and avoid the depression and problems that would interfere with her life. Hopefully, by having emotional quotient in a person, he can have the professionalism and responsibility in their duties within the organization.

\section{LITERATURE REVIEW}

Role reflect a pattern of behavior that a person lived, and reflects the position of a person in a position in society to interact with one another era, with all the rights and responsibilities that accompany it (Turner, 2006), According to Judge \& Robbins (2008), The role is a pattern of behavior that is closely related to someone who occupies a particular position in a social unit. Simply put, according toLubis (2010) role is part of people interacting.

Each individual has a role undertaken different behavior anyway. As an example in the world of work an employee can have more than one role, namely as a person subordinates, supervisors, union members, and also can be as a representative in work safety committee(Agustina, 2011), It also happens to auditors, as said Locke (1976) inSetiawan \& Ghozali (2006), That the responsibility of an auditor is not only required to meet the wishes of the clients who use the services, but also to serve the community.

An auditor also has many roles in his life. As a wife or husband or child or other role in their daily lives, it will not simply escape from the professionalism of the performance of an auditor. When there are problems or pressure as a result of his role in the personal life of an auditor, directly or indirectly affect the performance of the auditors concerned. The performance of a specified auditor of the factors surrounding it, not only in themselves but also the factor of external factors, so that the role that enveloped also give effect to focus the auditor to achieve optimal performance.

Examining the Audit Board of the Republic of Indonesia as an external audit of state finances, and as the spearhead investigations, they besides must be independent, competent, professional, objective, fact-based, they are also expected not to take sides. The theory of the role that used in this study can be applied to analyze the relationship between individuals, individuals with a collection of groups, or between groups of individuals. In other words can be applied to analyze the relationship between social interactions that involves the examiner Audit Board of the Republic of Indonesia.

\section{HYPOTHESES DEVELOPMENT}

Role stress condition in which a person has difficulty to understand the task and its actual role. Someone who stress the role are seen, felt that the task he had too heavy, or sometimes they undergo a variety of roles in which they work (Sopiah, 2008), The emergence of stress is often associated with conflict and role ambiguity role. Role conflict arising from a mismatch between the expectations presented in the individual in the organization with others inside and outside the organization, while the role ambiguity arise as a result of insufficient information required to complete a task or job in a way that satisfy (Fanani et al., 2008), Their role conflict and role ambiguity is a matter of considerable influence on the job for the auditor. This can lead to degraded performance of the individuals working in an organization, so the effect on the quality of work produced is not in accordance with the expectations of the organization.

An auditor also has many roles in his life. As a wife or husband or child or other role in their daily lives, it will not simply escape from the professionalism of the performance of an auditor. When there are problems or pressure as a result of his role in the personal life of an 
auditor, directly or indirectly affect the performance of the auditors concerned. The performance of a specified auditor of the factors surrounding it, not only in themselves but also the factor of external factors, so that the role that enveloped also give effect to focus the auditor to achieve optimal performance. As said Locke (1976) in Setiawan \& Ghozali (2006) that the auditors are not only required to meet the wishes of the clients who use the services, but also to serve the community.

Study the influence of stress on the performance of the auditor's role has been done so far, most have the result that the role of stress has a negative effect on the performance of auditors (Afifah, Sari, Anugerah, \& Sanusi, 2015; Ermawati et al., 2014; Martaseli \& Nugroho, 2016; Yustiarti, Hasan, \& Hardi, 2016), Although the research conducted byPermana, Anugerah, \& Al Azhar (2016)the results obtained is the role of stress have a positive effect on the performance of the auditor, or it can be said according to the results he was getting the higher the auditor stress the higher the performance of an auditor. In contrast again to the research conducted by Rahmawati (2011), The research results influential role conflict in the auditor's performance, while role ambiguity has no effect on the performance of auditors. Reinforced by research from Ramadika, Nasir, \& Wiguna (2014), which states that the role of stress does not affect the performance of an auditor.

Cordes \& Dougherty (1993) in Jones III, Norman, \& Wier (2010) explained the many negative consequences of the relationship between the role of stress in individuals and organizations. Their emotional quotient is expected to prevent the negative things that are created from the pressure role. Emotional quotient requires us to be introspective in appreciating the listener or the feelings of others, as well as in response to a verse that should and should not we say, so we can control the emotions that we use in everyday life. According to Goleman (2009), Emotional intelligence is the ability to recognize your feelings and the feelings of others, to motivate yourself, and managing emotions well in ourselves and in relationships with others. In fact it should be recognized that emotional quotient has a role to suppress the role of stress that is negative to increase a person's job performance in an organizational environment. On the basis of such exposure, the research hypothesis is:

$\mathrm{H} 1$ : Emotional quotient can strengthen the influence of role stress on job performance an examiner.

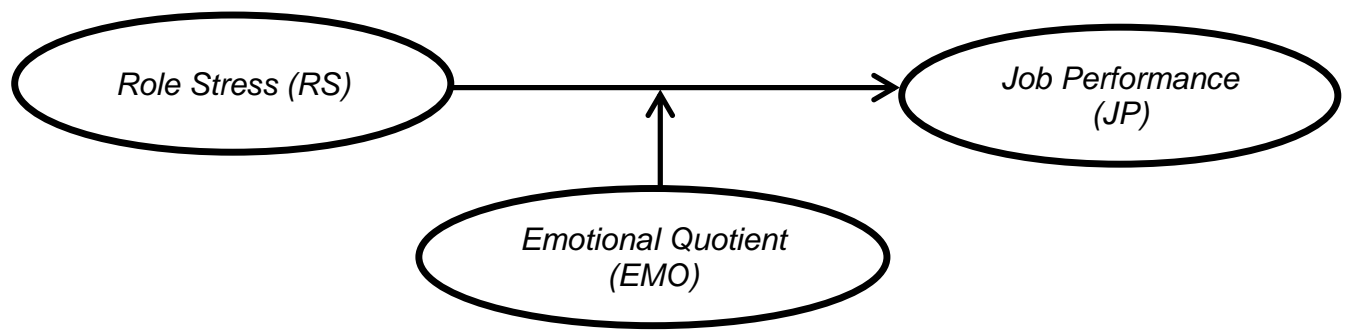

Figure 1 - Conceptual Framework

\section{METHODS OF RESEARCH}

The type of data in this research is quantitative data. Primary data in this study were obtained through questionnaires research as an answer of each respondent. The population in this study is all inspectors on work units Main Auditorat State Finance IV and the Bureau of Public Relations and International Cooperation of the Audit Board of the Republic of Indonesia, the total population is about 150 people. Samples in this study of 100 people. Questionnaires conducted with the approximate beginning of March - the end of April 2018. The technique used in the sampling was purposive sampling technique. Respondent's chosen based on considerations specific criteria. Criteria for the determination of a sample of respondents is the first working as an auditor at least 1 (one) year work period.

Data analysis techniques used in this study is Moderated Regression Analysis (MRA). The error rate $(\alpha)$ in this research set at $0.05(\alpha=5 \%)$. Conclusion is that if the significance value $>0.05$, then the hypothesis is accepted. 
The variable in this research is divided on the dependent variable, the variable mediator and the independent variables, where the variables used are:

- Role stress or stress caused by three main factors, namely the role ambiguity, role conflict and role overload (Gratia \& Septiani, 2014; Jones III et al., 2010; Sweeney, Bernardi, \& Arnold, 2014), This was triggered by the internal condition which is a consequence of their action or external situation a person both physically and psychologically. This variable was measured by using an instrument developed byRizzo, House, \& Lirtzman (1970) which has been adopted by Jones III et al. (2010) with seven Likert scale and by Fanani et al. (2008)with five Likert scale. This study adjusts using a Likert scale of five ratings, namely: value 1 = strongly disagree, 2 = disagree, 3 = undecided, $4=$ agree, 5 = strongly agree.

- Emotional quotient is the ability to recognize your feelings and the feelings of others, to motivate yourself, and managing emotions well in ourselves and in relationships with others (Goleman, 2009), This variable is measured using indicators adopted emotional quotient ofRahmawati (2011), Which is adapted to this research topic. This study adjusts using a Likert scale of five ratings, namely: value $1=$ strongly disagree, 2 = disagree, 3 = undecided, 4 = agree, 5 = strongly agree.

- Job performance can be high or low performance diartika that one can be a good influence for themselves and for the organization. A person who has a low performance, will lead to potential errors more likely to occur and ends on the declining credibility(Fisher, 2001), This variable was measured by using an instrument developed by(Kalbers \& Fogarty, 1995) which has been adopted Fanani et al. (2008) This uses five scale Likert: value $1=$ strongly disagree, $2=$ disagree, $3=$ undecided, 4 = agree, 5 = strongly agree.

\section{RESULTS AND DISCUSSION}

Testing the hypothesis in this study was conducted using three regression model in order to determine what kind of moderation that is owned by the variable quotient on the independent variable (role stress), including moderating variables pure (pure moderator) moderating variable pseudo (quasi moderator), variable potential, or independent variables. The regression equation in this study as follows:

$$
\begin{aligned}
& \text { Model 1: JP }=a_{1}+b_{1} R S+e_{1} \\
& \text { Model 2: JP }=a_{2}+b_{2} R S+b_{3} E M O+e_{2} \\
& \text { Model 3: JP }=a_{3}+b_{4} R S+b_{5} E M O+b_{6} R S * E M O+e_{3}
\end{aligned}
$$

Where: JP = Job Performance; $a=$ constant $; b=$ Regression Coefficients; RS = Role Stress; $\mathrm{EMO}=$ Emotional Quotient; HLEMO = variable role stress multiplication with emotional quotient (describe the moderating variables emotional quotient of the influence of role stress with job performance); $\mathrm{e}=$ error.

Table 1 - Hypothesis Testing Results

\begin{tabular}{|l|l|l|l|l|}
\hline Hypothesis & Variables & B & t & Sig. \\
\hline \multirow{5}{*}{ Hypothesis 1 } & Model 1 & & \\
\cline { 2 - 5 } & Role Stress (RS) & -0236 & -2739 & 0007 \\
\cline { 2 - 5 } & Model 2 & & & \\
\cline { 2 - 5 } & Role Stress (RS) & -0484 & -5371 & 0000 \\
\cline { 2 - 5 } & Emotional Quotient (EMO) & 1,081 & 5,217 & 0000 \\
\cline { 2 - 5 } & Model 3 & & & \\
\cline { 2 - 5 } & Role Stress (RS) & -3839 & -2307 & 0023 \\
\cline { 2 - 5 } & Emotional Quotient (EMO) & -2070 & -1315 & 0192 \\
\cline { 2 - 5 } & Role Stress * Emotional Quotient (RSEMO) & 0906 & 2,019 & 0046 \\
\hline
\end{tabular}

Source: Results of data processing SPSS 22.0 for Windows.

Note: The amount of data (observations) = 100; T table value: $\alpha=5 \%=1.66071 ;$ Dependent Variables $=J P$. 
Results of regression testing successfully support the hypothesis 1 , which means that in condition emotional quotient is high, the influence of the role stress on job performance will increase with $t$ significance of the interaction of RS and EMO is under the value of $\alpha=5 \%$ that is 0046 , and the value of $t$ greater than t table (RSEMO $=2,019)$.

Variable Types emotional quotient in this equation can be determined by looking at the significance of regression coefficients in equation (2) b3EMO, b3 namely 0.000 (significant) and the equation (3) b6RSEMO, b6 namely 0.000 (significant), so this shows that the variable quotient the influence of role stress on job performance quasi act as a moderating variable. Moderating variable quasi (pseudo), is a variable that moderates the relationship between independent variables and the dependent variable where variable apparent moderation interact with the independent variables at once become independent variable.

For the sake of clarifying the nature and direction of each of the variables, we perform a mathematical calculation of derivation partial results are presented in graphical form. The goal is to be able to know whether the effect of role stress on job performance will be constant along the emotional quotient. If constant, it will clarify the influence of monotonic; otherwise if not constant then it will show a non-monotonic relationship.

The regression equation of the first hypothesis testing results is:

$$
J P=(12559)-3.839 R S-2.070 E M O+0.906 R S E M O
$$

Its partial derivation equation is:

$$
\begin{gathered}
\partial \mathrm{JP} / \partial \mathrm{RS}=-3,839+0.906 \mathrm{EMO} \\
\text { For } \mathrm{EMO}=0, \text { then } \partial \mathrm{JP} / \partial \mathrm{RS}=-3,839 \\
\text { For } \partial \mathrm{JP} / \partial \mathrm{RS}=0, \text { then } \\
0=-3,839+0.906 \mathrm{EMO} \\
3,839=0.906 \mathrm{EMO} \\
\mathrm{EMO}=3839 / 0906 \\
\mathrm{EMO}=4,237
\end{gathered}
$$
2 below:

To clarify the direction and effect non-monotonic of each variable can be seen in Figure

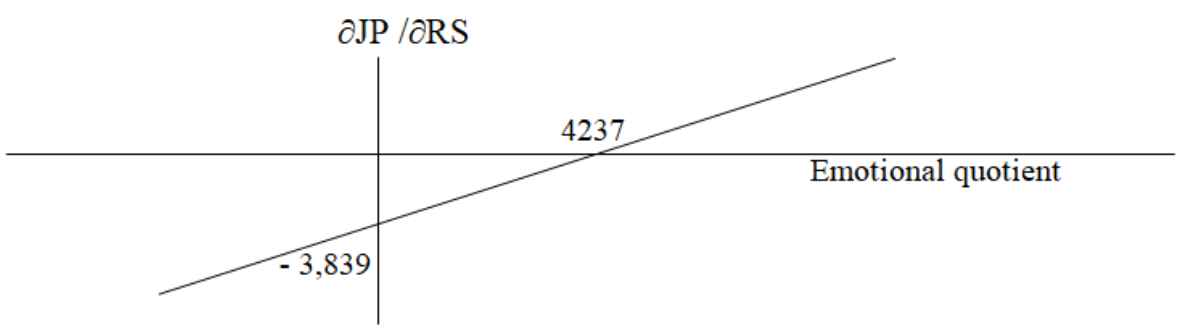

Figure 2 - Interaction between Role Stress with Emotional Quotient against Job Performance

The results of the calculation, that point which intersects the axis JP $\partial \mathrm{JP} / \partial \mathrm{RS}$ is -3839 , on the other hand the point that intersects the axis EMO is 4237 hereinafter referred to as the inflection point. Figure 2 shows the results of the above calculations clarify the direction and non-monotonic effect of each variable. It has been suggested that the increased emotional quotient will lead to increased job performance, and vice versa if the quotient decreases causing a decrease in job performance. With a significance value less than 0.05 (ie 0046) and $t$ table is smaller than $t$ ie (1.66071> 2019), the first hypothesis which states can strengthen the emotional quotient negative influences role stressors on a checker acceptable job performance.

The results of this study support the hypothesis first successful meaningful role emotional quotient strengthen the influence of stress on an examiner's job performance. Or it 
could be said that emotional quotient improvement will lead to increased job performance, and vice versa if the quotient decreases causing a decrease in job performance.

This study concurs with research conducted by Afifah et al. (2015); Ermawati et al. (2014); Yustiarti et al. (2016), Pressure due to the role or task (role stress) a condition in which a person has difficulty in understanding what the duties according to this study did not occur in the inspectors of the Audit Board of the Republic of Indonesia, though from this study proved that in the absence of pressure role felt by the examiner and management coupled with high emotional intelligence, the inspectors job performance can be increased.

Audit Board of the Republic of Indonesia implementing e-audit to improve the efficiency and effectiveness of the implementation and reporting of test results. These efforts and other efforts have helped the Audit Board of the Republic of Indonesia to resolve the gap between high workload with limited resources. According Accountability Report Audit Board of the Republic of Indonesia, in 2013 the performance scores of the Audit Board of the Republic of Indonesia had reached 88.97, the year 2014 is 89.23, 2015 amounted to 94.14, in 2016 amounted to 97,70 with a trend that continues to rise, so it is clear that the work environment of the Audit Board of the Republic of Indonesia of human resources who have a mechanism to anticipate the pressure of everyday work life.

\section{CONCLUSION}

Management of human resources of the Audit Board of the Republic of Indonesia has been done professionally with the implementation of Plan of Human Resources Management (HRM Plan) in performing their duties so as to produce high motivation and competence is adequate. Work in the Audit Board of the Republic of Indonesia system has been defined both by the organization and division of tasks and roles tailored to each individual office, so there is no overlap between the roles of an employee. Supervision is done by the senior and junior indicated in accordance with the portion of the appropriate level of respective positions, so there is no pressure felt by the examiner, paired well with the emotional intelligence that a contributing factor to affect the roles of stress on employee performance respectively, more performance goes well.

\section{SUGGESTIONS}

The advice given by the author is for Audit Board staff of the Republic of Indonesia is, to continue to maintain the performance of each individual in aligning organizational goals. For the Audit Board of the Republic of Indonesia, to maintain the quality of human resources $(\mathrm{HR})$ to support optimal performance both in terms of role stress and also emotional intelligence and daily operational activities or office gathering together.

\section{REFERENCES}

1. Afifah, U., Sari, R. N., Anugerah, R., \& Sanusi, Z. M. (2015). The Effect of Role Conflict, Self-efficacy, Professional Ethical Sensitivity on Auditor Performance with Emotional Quotient as Moderating Variable. Procedia Economics and Finance, 31, 206-212. ISSN: 2212-5671.

2. Agustina, L. (2011). Pengaruh Konflik Peran, Ketidakjelasan Peran, dan Kelebihan Peran terhadap Kepuasan Kerja dan Kinerja Auditor (Penelitian pada Kantor Akuntan Publik yang Bermitra Dengan Kantor Akuntan Publik Big Four di Wilayah DKI Jakarta). Jurnal Akuntansi, 1(1), 40-69.

3. Chen, J.-C., Silverthorne, C., \& Hung, J.-Y. (2006). Organization communication, job stress, organizational commitment, and job performance of accounting professionals in Taiwan and America. Leadership \& organization Development journal, 27(4), 242-249. ISSN: 0143-7739. 
4. Cianci, A. M., \& Bierstaker, J. L. (2009). The impact of positive and negative mood on the hypothesis generation and ethical judgments of auditors. Auditing: A Journal of Practice \& Theory, 28(2), 119-144. ISSN: 0278-0380.

5. Coenen, T. L. (2008). Essentials of corporate fraud (Vol. 37): John Wiley \& Sons.

6. Cote, S., \& Miners, C. T. (2006). Emotional intelligence, cognitive intelligence, and job performance. Administrative science quarterly, 51(1), 1-28. ISSN: 0001-8392.

7. Ermawati, M. D., Sinarwati, N. K., \& Edy Sujana, S. (2014). Pengaruh Role Stress terhadap Kinerja Auditor dengan Emotional Quotient Sebagai Variabel Moderating (Studi Empiris pada Kantor Akuntan Publik di Bali) JIMAT (Jurnal IImiah Mahasiswa Akuntansi S1), 2(1).

8. Fanani, Z., Hanif, R. A., \& Subroto, B. (2008). Pengaruh Struktur Audit, Konflik Peran, dan Ketidakjelasan Peran Terhadap Kinerja Auditor. Jurnal Akuntansi dan Keuangan Indonesia 5(02), 139-155. ISSN: 0853-7593.

9. Fisher, R. T. (2001). Role stress, the type A behavior pattern, and external auditor job satisfaction and performance. Behavioral Research in Accounting, 13(1), 143-170. ISSN: 1050-4753.

10. Fogarty, T. J., Singh, J., Rhoads, G. K., \& Moore, R. K. (2000). Antecedents and consequences of burnout in accounting: Beyond the role stress model. Behavioral Research in Accounting, 12, 31. ISSN: 1050-4753.

11. Gibbs, N., \& Epperson, S. 1995. The EQ factor. Time, 146, 60-67.

12. Goleman, D. (2009). Kecerdasan Emosional: Mengapa El lebih penting daripada IQ.

13. Gratia, A. A., \& Septiani, A. (2014). Pengaruh Gaya Hidup Sehat Terhadap Psychological Well-being Dan Dampaknya Pada Auditor KAP (Studi Empiris pada Auditor Kantor Akuntan Publik di Jawa Tengah Dan DIY). Diponegoro Journal of Accounting, 3(2), 1-12.

14. Hatfield, R. C., Jackson, S. B., \& Vandervelde, S. D. (2011). The effects of prior auditor involvement and client pressure on proposed audit adjustments. Behavioral Research in Accounting, 23(2), 117-130. ISSN: 1050-4753.

15. Hayes, C. T., \& Weathington, B. L. (2007). Optimism, stress, life satisfaction, and job burnout in restaurant managers. The Journal of psychology, 141(6), 565-579. ISSN: 0022-3980.

16. Jones III, A., Norman, C. S., \& Wier, B. (2010). Healthy lifestyle as a coping mechanism for role stress in public accounting. Behavioral Research in Accounting, 22(1), 21-41. ISSN: 1050-4753.

17. Judge, T. A., \& Robbins, S. P. (2008). Perilaku organisasi. Jakarta: Salemba Empat.

18. Kalbers, L. P., \& Fogarty, T. J. (1995). Professionalism and its consequences: A study of internal auditors. Auditing, 14(1), 64. ISSN: 0278-0380.

19. Kip Holderness, D., \& Hunton, J. E. (2010). Examining the antecedents and consequences of regular exercise in the audit profession: How CPA firms can promote auditors' psychological and physical healthiness Advances in Accounting Behavioral Research (pp. 143-168): Emerald Group Publishing Limited.

20. Lawrence, T. B., \& Robinson, S. L. (2007). Ain't misbehavin: Workplace deviance as organizational resistance. Journal of management, 33(3), 378-394. ISSN: 0149-2063.

21. Le Fevre, M., Matheny, J., \& Kolt, G. S. (2003). Eustress, distress, and interpretation in occupational stress. Journal of managerial Psychology, 18(7), 726-744. ISSN: 02683946.

22. Lubis, A. I. (2010). Akuntansi Keperilakuan. Jakarta: Salemba Empat.

23. Martaseli, E., \& Nugroho, G. W. (2016). Pengaruh Tingkat Stres Terhadap Kinerja Auditor di Kantor BPKP Perwakilan DKI Jakarta. Syariah Paper Accounting FEB Universitas Muhammadiya Surakarta. ISSN: 2460-0784.

24. Nasution, D., \& Östermark, R. (2012). The impact of social pressures, locus of control, and professional commitment on auditors' judgment: Indonesian evidence. Asian Review of Accounting, 20(2), 163-178. ISSN: 1321-7348.

25. Notoprasetio, C. G. (2012). Pengaruh Kecerdasan Emosional dan Kecerdasan Spiritual Auditor terhadap Kinerja Auditor pada Kantor Akuntan Publik di Surabaya. Jurnal IImiah Mahasiswa Akuntansi, 1(4), 76-81. ISSN: 2303-1727. 
26. Permana, Y., Anugerah, R., \& Al Azhar, L. (2016). Analisis Pengaruh Motivasi, Stress, dan Rekan Kerja Terhadap Kinerja Auditor di Kantor Badan Pengawas Keuangan dan Pembangunan Riau dan Sumatera Utara. Jurnal Online Mahasiswa (JOM) Bidang IImu Ekonomi, 3(1), 1350-1364. ISSN: 2355-6854.

27. Rahmawati. (2011). Pengaruh Role Stress Terhadap Kinerja Auditor Dengan Emotional Quotient Sebagai Variabel Moderating. Skripsi. Universitas Islam Negeri Syarif Hidayatullah Jakarta.

28. Ramadika, A. P., Nasir, A., \& Wiguna, M. (2014). Pengaruh role stress, gender, struktur audit dan profesionalisme terhadap kinerja auditor bpk-ri perwakilan provinsi riau. Jurnal Online Mahasiswa (JOM) Bidang IImu Ekonomi, 1(2), 1-15. ISSN: 2355-6854.

29. Rizzo, J. R., House, R. J., \& Lirtzman, S. I. (1970). Role conflict and ambiguity in complex organizations. Administrative science quarterly, 150-163. ISSN: 0001-8392.

30. Rustiarini, N. W. (2014). Sifat Kepribadian Sebagai Pemoderasi Hubungan Stres Kerja Dan Perilaku Disfungsional Audit. Jurnal Akuntansi dan Keuangan Indonesia, 11(1), 119. ISSN: 2406-9701.

31. Schick, A. G., Gordon, L. A., \& Haka, S. (1990). Information overload: A temporal approach. Accounting, Organizations and Society, 15(3), 199-220. ISSN: 0361-3682.

32. Setiawan, I. A., \& Ghozali, I. (2006). Akuntansi Keperilakuan: Konsep dan Kajian Empiris Perilaku Akuntan. Semarang: Badan Penerbit Universitas Diponegoro.

33. Sopiah. (2008). Perilaku Organisasi. Yogyakarta: Andi.

34. Sweeney, C. J., Bernardi, R. A., \& Arnold, D. F. (2014). Could the Level of Personal Indebtedness Influence an Auditor's Professional Decision-Making Process? Research on Professional Responsibility and Ethics in Accounting, 89-108. ISSN: 1574-0765.

35. Turner, J. H. (2006). Handbook of sociological theory: Springer Science \& Business Media.

36. Yustiarti, F., Hasan, A., \& Hardi. (2016). Pengaruh Konflik Peran, Ketidakjelasan Peran, dan Kelebihan Peran Terhadap Kinerja Auditor dengan Kecerdasan Emosional Sebagai Pemoderasi (Studi Empiris pada KAP di Pekanbaru, Padang dan Medan) Jurnal Akuntansi (Media Riset Akuntansi \& Keuangan), 5(1), 12-28. ISSN: 2337-4314. 